\title{
Impatiens jenjittikuliae (Balsaminaceae), a new species from Thailand
}

\author{
Saroj Ruchisansakun', Piyakaset Suksathan ${ }^{2}$ \\ I Department of Plant Science, Faculty of Science, Mahidol University, Bangkok, Thailand 2 Queen Sirikit \\ Botanic Garden, The Botanical Garden Organization, Chiang Mai, Thailand \\ Corresponding author: Saroj Ruchisansakun (s.ruchisansakun@gmail.com)
}

Academic editor: Y. Mutafchiev | Received 2 February 2019 | Accepted 13 May 2019 | Published 21 June 2019

Citation: Ruchisansakun S, Suksathan P (2019) Impatiens jenjittikuliae (Balsaminaceae), a new species from Thailand. PhytoKeys 124: 139-147. https://doi.org/10.3897/phytokeys.124.33607

\begin{abstract}
Impatiens jenjittikuliae Ruchis. \& Suksathan, a new species from a limestone area in Thasongyang District, Tak Province, Northern Thailand, is described and illustrated. This endemic new species is distinguished from the most similar, I. lacei Hook.f. through having pilose lateral sepals vs glabrous, and by the absence of long hairs along the lamina margin. Its pollen and seed morphology, stem anatomy, and pollination ecology are also observed. Furthermore, its conservation status as Critically Endangered is also assessed.
\end{abstract}

\section{Keywords}

Uniflorae, lithophytic, endemic, critically endangered

\section{Introduction}

Balsaminaceae consists of Hydrocera Blume ex Wight \& Arnott (1834: 140) with only a single species, H. triflora (L.) Wight \& Arnott (1834: 140), and Impatiens L. (1753: 937), comprising over 1,000 species (Ruchisansakun et al. 2018). In Southeast Asia, many new Impatiens species were recently described (Souvannakhoummane and Suksathan 2015; Ruchisansakun et al. 2017; Ruchisansakun et al. 2018; Suksathan and Triboun 2009).

In Thailand, sixty-one native Impatiens species have been enumerated in previous works (Shimizu 1970, 1977, 1991, 2000; Shimizu and Suksathan 2004; Suksathan 
and Triboun 2009; Ruchisansakun et al. 2014). In 2017, the first author cited here noticed an unnamed Impatiens from Tak Province via Weerayuth Laohajinda's Facebook and later on traveled to examine the plant in 2018. After a detailed study, it turned out to be a species new to science. It is therefore described here.

\section{Material and methods}

Fieldwork was conducted in October 2018. The plants were prepared for making herbarium specimens. Each part of the flower was separately glued on the hard paper and dried separately. All parts were measured and described in line with terminology in Ruchisansakun et al. (2018). For a palynological study, mature pollen grains were collected, air-dried, and fixed to aluminum stubs, then sputter-coated with gold. Micrographs were taken with a Field Emission Scanning Electron Microscope (FE-SEM) (Hitachi SU8010). The pollen grains and seeds were measured by ImageJ and described according to the terminology of pollen grains and seeds (Janssens et al. 2012). For an anatomical study, the fresh stem was dissected at the base and stained by diluted Safranin-O for $20 \mathrm{sec}$, and observed under a light microscope.

\section{Result}

Taxonomy

Impatiens jenjittikuliae Ruchis. \& Suksathan, sp. nov. urn:Isid:ipni.org:names:77198714-1

Figs $1-5$

Diagnosis. Impatiens jenjittikuliae is most similar to I. lacei Hook.f. It differs from I. lacei by its densely pilose lateral sepal (versus glabrous) and by having no long hairs along its lamina margin (versus distinct long hairs especially along the lower-half of leaf margin).

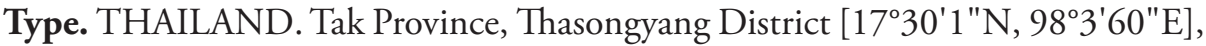
limestone area near waterfall in mixed deciduous forest at $540 \mathrm{~m}$ alt., 20 October 2018, S. Ruchisansakun 900 (holotype: QBG; isotypes: BK, BKF, Mahidol University Herbarium)

Description. Lithophytic, annual herb, up to $6-30 \mathrm{~cm}$ tall. Stem erect, up to 1.2 $\mathrm{cm}$ in diam., cylindrical, branched, green, densely pilose with short white hairs. Leaves spirally arranged. Petiole $3-7.5 \mathrm{~cm}$ long, ca. $2.5 \mathrm{~mm}$ in diam., pale green to green to pink, pilose; with 5-7 pairs of long hairs on petiole, up to $2 \mathrm{~mm}$ long, green, sometime with red tips. Lamina 9-20 × 3-7 cm, ovate to elliptic, apex acute, base cuneate, margin shallowly serrate, adaxial green, abaxial pale green, pilose on both sides; lateral veins 10-12 pairs. Inflorescence raceme, axillary, 8-12 florets; peduncle 7-10 mm 

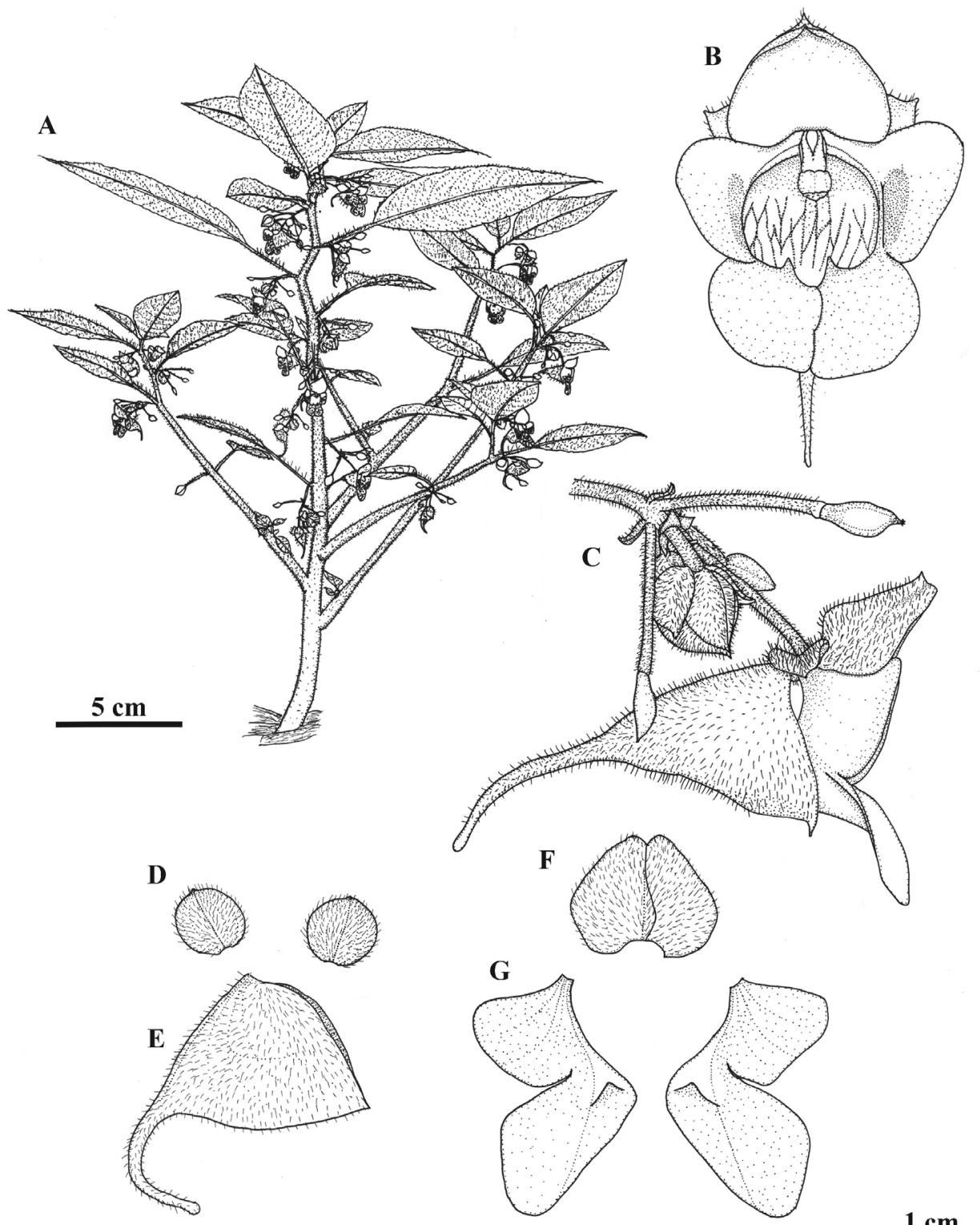

$1 \mathrm{~cm}$

Figure I. Impatiens jenjittikuliae. A Habit B Flower, front view C Inflorescence with flower in lateral view D Lateral sepals E Lower sepal F Dorsal petal G Lateral united petals. Drawn by Saroj Ruchisansakun.

long, $1.5-2 \mathrm{~mm}$ in diam., pale green, densely pilose; rachis $8-20 \mathrm{~mm}$ long, ca. $1.5 \mathrm{~mm}$ in diam., pale green, densely pilose, hairs shorter than those on peduncle. Flowers ca. $20 \times$ ca. $15 \mathrm{~mm}$, ca $3 \mathrm{~mm}$ deep, pinkish white with reddish purple lip. Bracts ca. $1 \times$ $0.5 \mathrm{~mm}$, linear to narrowly lanceolate, apex acute, base cuneate, green, caducous, abaxial densely pilose with white hairs. Pedicel $12-15 \mathrm{~mm}$ long, less than $1 \mathrm{~mm}$ in diam., 

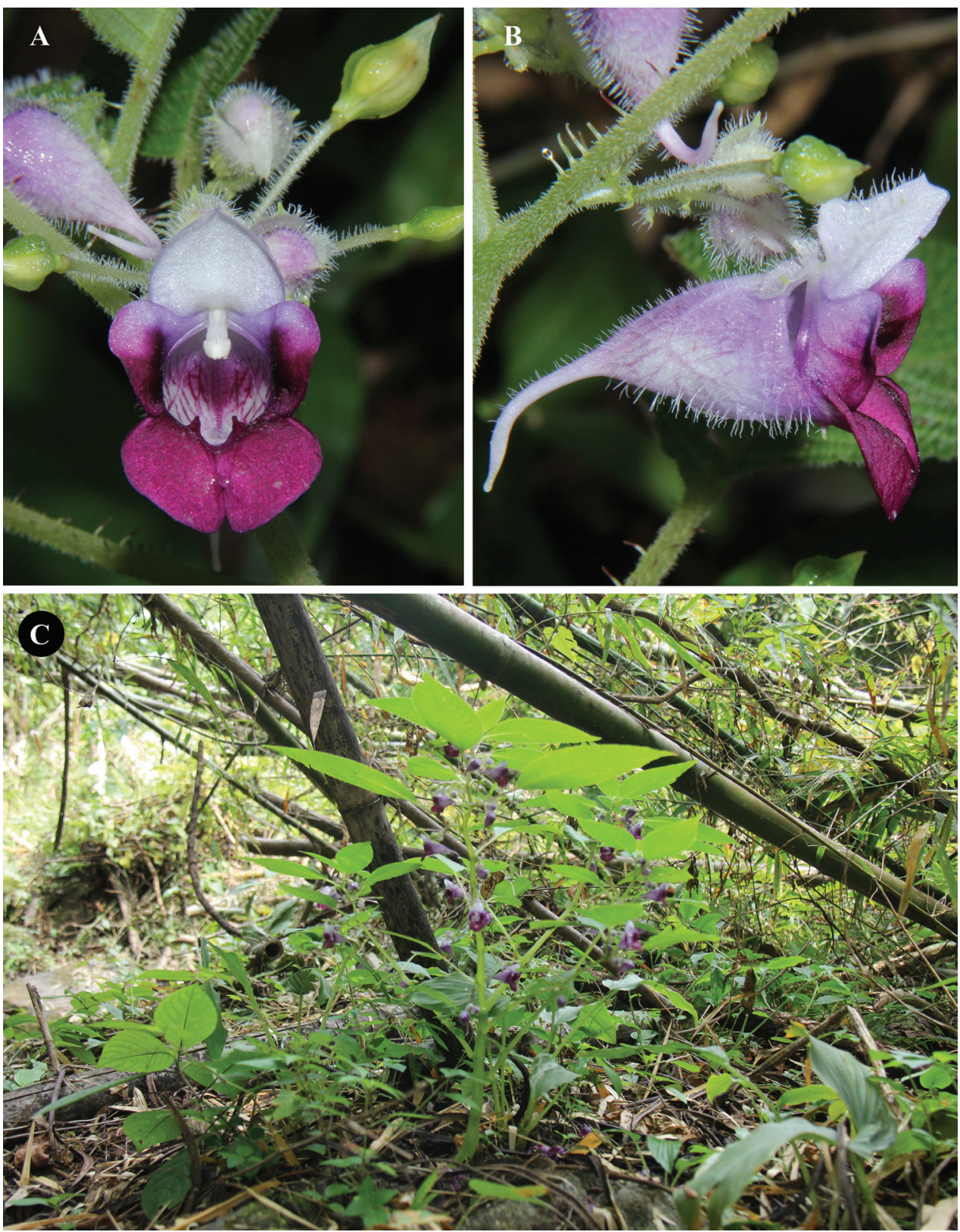

Figure 2. Impatiens jenjittikuliae $\mathbf{A}$ flower, front view $\mathbf{B}$ flower, lateral view $\mathbf{C}$ habit in situ. Photographs by Saroj Ruchisansakun.

pink, densely pilose with white hairs. Lateral sepals 2, 5-6 × 6-7 mm, free, broadly ovate, the apex mucronate, the base truncate, pale pink, abaxially densely pilose with white hairs. Lower sepal 11-13 × 8-10 mm, ca. 14-17 mm deep, broadly navicular to subsaccate, apex acuminate and mucronate, white with green tip, densely pilose to 

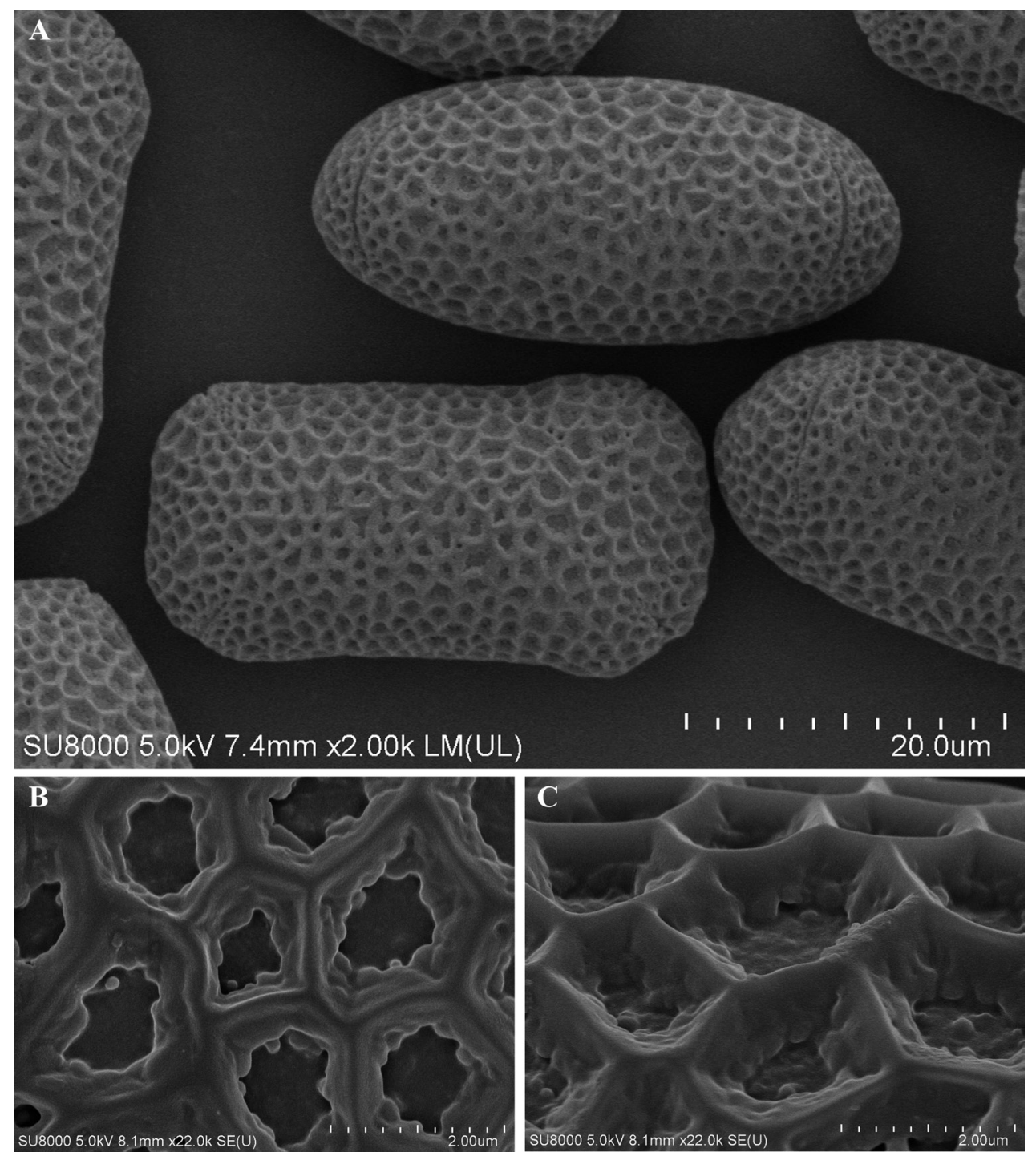

Figure 3. Pollen of Impatiens jenjittikuliae (FE SEM) A entire pollens B, C sexine ornamentation.

strigose outside with long white hairs, distal part gradually constricted into a curved spur, 14-15 mm long, white to pale pink. Dorsal petal 11-12 × 14-15 mm, broadly ovate to obcordate, cucullate, apex emarginate and mucronate, base cordate, white to pale pink, densely pilose with white hairs, abaxial midvein with a white crescentshaped crest, 1-1.5 mm high. Lateral united petals 20-24 $\mathrm{mm}$ long, free: the upper petals $9-10 \times 10-11 \mathrm{~mm}$, broadly oblong, apex truncate, base cuneate, upper outer part white to pale pink, lower inner part dark purple; the lower petals $17-19 \times 8-10$ $\mathrm{mm}$, oblong, apex truncate, pink to reddish-purple; with a pink auricle at the base, ca $1 \mathrm{~mm}$ high. Stamens 5; filaments 4-5 mm long, white; anthers white. Ovary ca $4 \mathrm{~mm}$ 


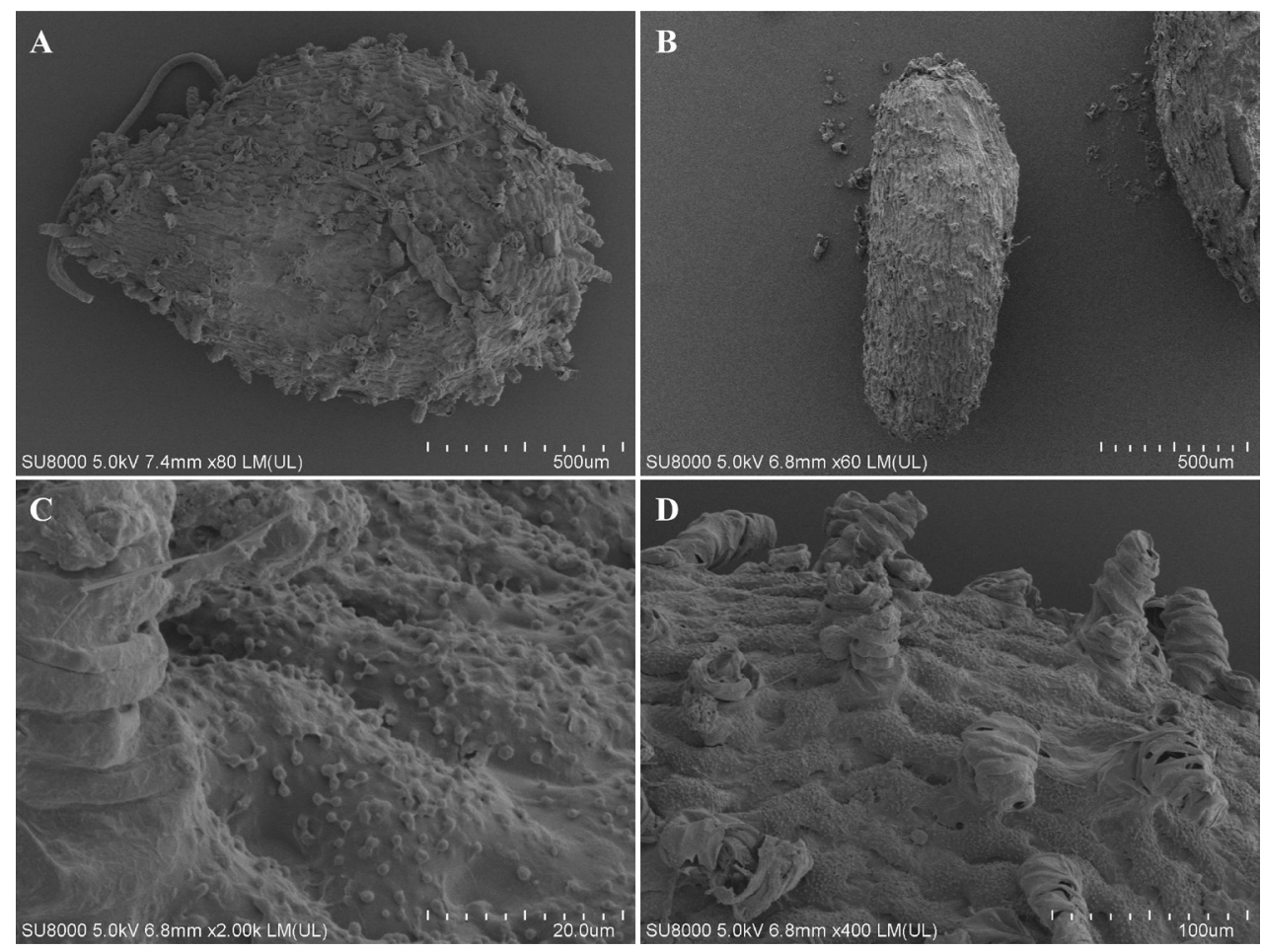

Figure 4. Seed of Impatiens jenjittikuliae (FE SEM). A, B Entire seeds C Inflated cells with granulate walls $\mathbf{D}$ Thick finger-like cells.

long, $1.5-2 \mathrm{~mm}$ in diam., short fusiform, 5-carpellate, green, glabrous. Fruits, short fusiform capsule, 11-12 mm long, 6-8 $\mathrm{mm}$ in diam., subglobose, 5-lobed, green, glabrous. Seeds ca. 20 per fruit, ca. 1.34 mm long, ovoid, brown.

Pollen morphology: Pollen grains 4-colpate (Fig. 3A). Equatorial view oblong, ca $35 \times 18-19 \mu \mathrm{m}$ (length/width = 1.89); Polar view nearly elliptic, ca. $17 \mu \mathrm{m}$ thick, colpi four, linear, ca 9-10 $\mu \mathrm{m}$ (Fig. 3A); surface entirely covered with numerous irregular lumens, 1.2-2 $\mu \mathrm{m}$ diam, lumens deep, sparsely granulate (Fig. 3B); muri slightly straight, joint of muri slightly corniculate (Fig. 3C).

Seed morphology: Brown ovoid, ca $1.34 \times 0.93 \mathrm{~mm}$, ca $0.51 \mu \mathrm{m}$ thick (length/ width $=1.44)($ Fig. 4). Seed coat a composite of two types, thick finger-like cells, and inflated cells with granulate walls (Figs. 4C, D).

Stem anatomy: Stem herbaceous, without lignification (Figs 5A-C). Only angular collenchyma for stem-strengthen were found (Fig. 5D).

Phenology. Flowering from Oct. to Nov.; fruiting Oct. from Nov.

Distribution. The new species is only known from the type locality in Tak Province, Thailand. 


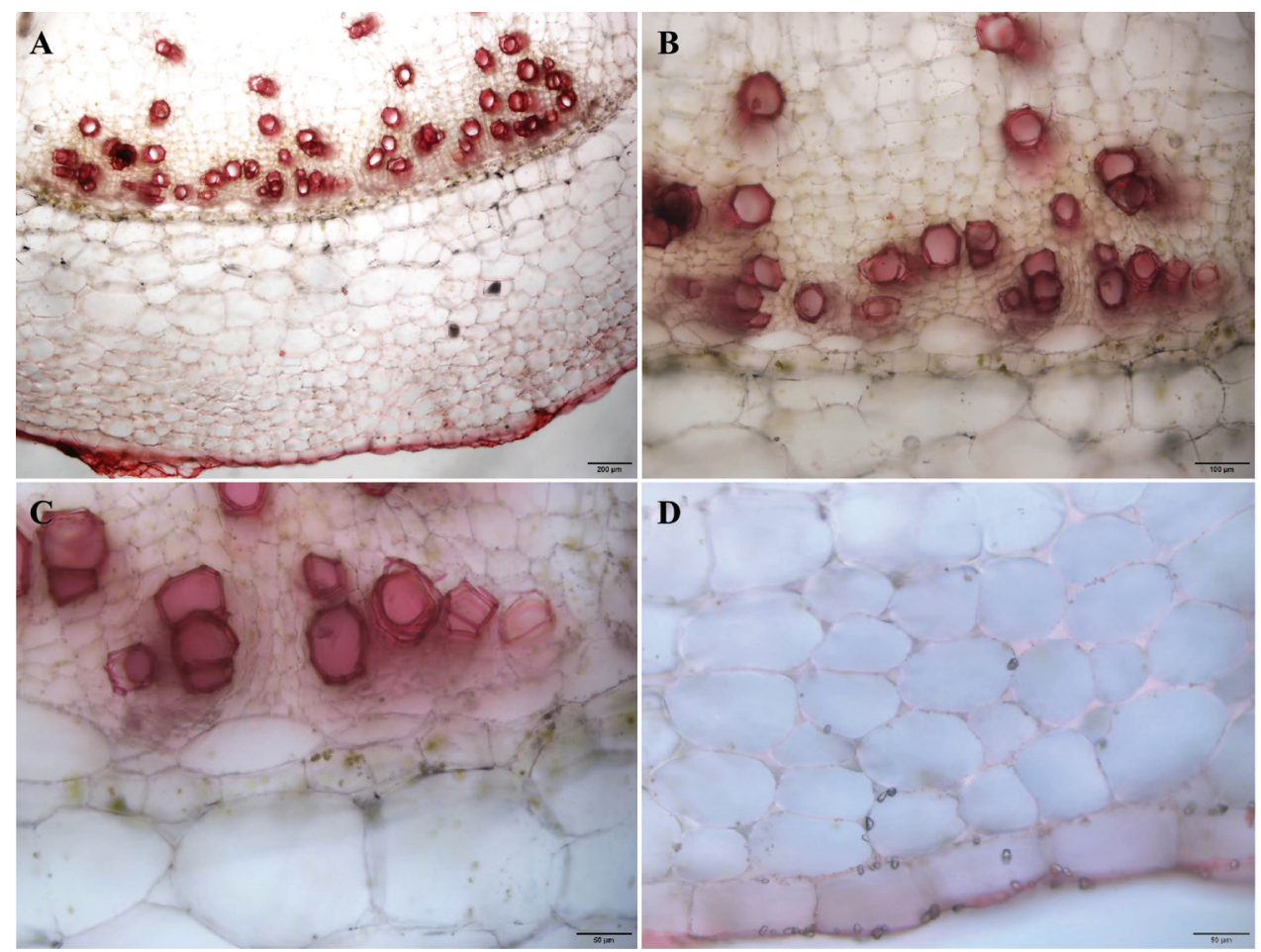

Figure 5. Stem of Impatiens jenjittikuliae, transverse sections.
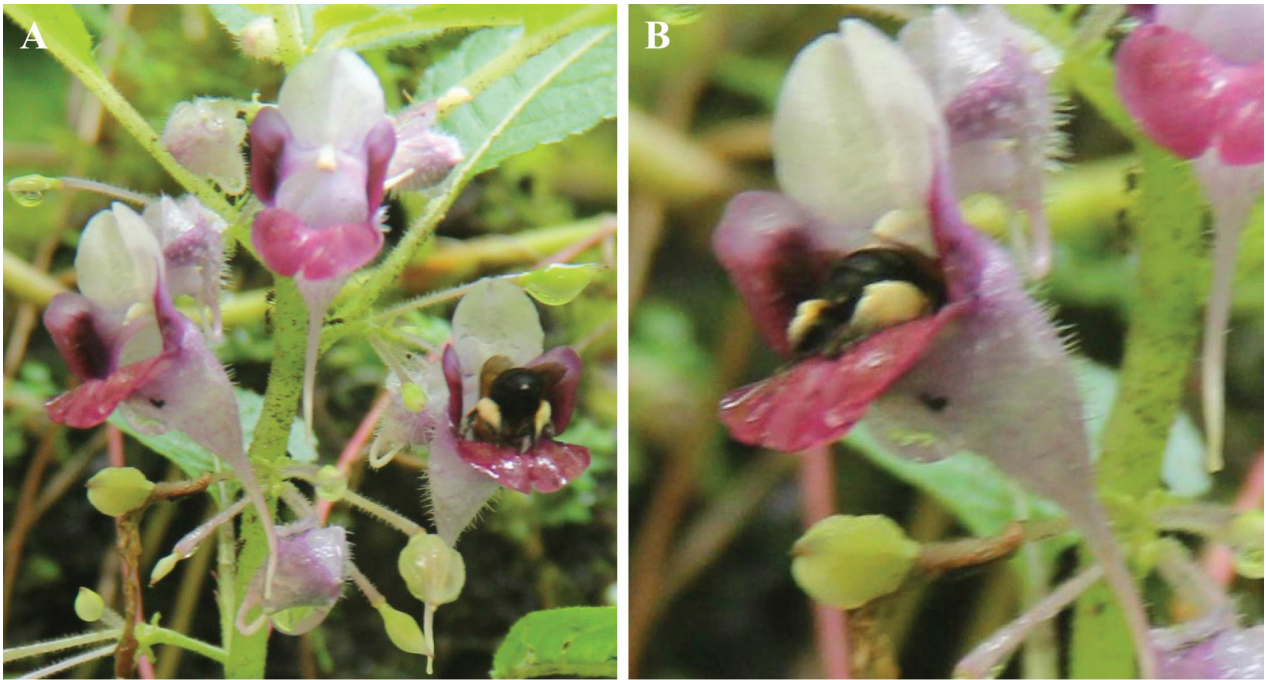

Figure 6. Floral visitation by bee in the locality of Impatiens jenjittikuliae. 
Ecology. Impatiens jenjittikuliae grows on limestone close to waterfall in a mixed deciduous forest, 520-600 m elevation (pers. obs.).

Proposed IUCN conservation assessment. Critically Endangered B1ab (i, ii, iii) + $2 \mathrm{ab}$ (i, ii, iii). This species is only known from the type locality; the extent of occurrence is estimated to be less than $5 \mathrm{~km}$, where it occurs as a small population (IUCN 2012).

Etymology. The new species is named in honor of Dr. Thaya Jenjittikul who encouraged the first author to step in and study this lovely plant family.

Pollination ecology. The author observed five visitations by bees from the family Apidae (identified by an entomologist, Pornpimon Tangtorwongsakul) during the expeditions. The size of bee body fit well with the floral entrance (Fig. 6). Moreover, the floral structure of this new species is similar to other bee-pollinated species, e.g. I. psittacina (Ruchisansakun et al. 2016). Hence, we concluded that it is a bee-pollinated species.

\section{Discussion}

Impatiens jenjittikuliae is similar to $I$. lacei and the other species closely related to I. pulchra Hook.f (= I. mengtszeana Hook.f. in Ruchisansakun et al. 2015) in its raceme inflorescence, shape of flower, and short fusiform capsule. The short fusiform capsule and the 4-colpate pollen grains of the new species support its placement in the subgenus Impatiens (Yu et al. 2015). In addition, I. jenjittikuliae has seeds coated with inflated cells with granulate walls similar to those described in species, such as I. napoensis Y. L. Chen, within the sect. Uniflorae (Janssens et al. 2012; Yu et al. 2015).

The cross sections of the stem of I. jenjittikuliae have shown that the new species is herbaceous, similar to the morphologically similar species in the sect. Uniflorae, I. pulchra, which also show in Lens et al. (2012) as I. mengtszeana Hook.f. (Lens et al. 2012; Ruchisansakun et al. 2015; Yu et al. 2015).

\section{Acknowledgements}

We would like to thank Frederic Lens, Larissa Chacon-Doria, Pantamith Ratanakrajang, Pornpimon Tangtorwongsakul, and Weerayuth Laohajinda, for their help with different parts of this work.

\section{References}

IUCN (2012) IUCN Red List Categories and Criteria: Version 3.1 (2 $2^{\text {nd }}$ edn). Glandand Cambridge, $32 \mathrm{pp}$.

Janssens SB, Wilson SY, Yuan YM, Nagels A, Smets EF, Huysmans S (2012) A total evidence approach using palynological characters to infer the complex evolutionary history of the Asian Impatiens (Balsaminaceae). Taxon 61(2): 355-367. https://doi.org/10.1002/tax.612007 
Lens F, Eeckhout S, Zwartjes R, Smets EF, Janssens SB (2012) The multiple fuzzy origins of woodiness within Balsaminaceae using an integrated approach. Where do we draw the line? Annals of Botany 109(4): 783-799. https://doi.org/10.1093/aob/mcr310

Linneaus C (1753) Species Plantarum 2. Laurentius Salvius, Stockholm, 639 pp.

Ruchisansakun S, Triboun P, Jenjittikul T (2014) A new species of Impatiens (Balsaminaceae) from Southwestern Thailand. Phytotaxa 174(4): 237-241. https://doi.org/10.11646/phytotaxa.174.4.5

Ruchisansakun S, Van der Niet T, Janssens SB, Triboun P, Techaprasan J, Jenjittikul T, Suksathan P (2015) Phylogenetic analyses of molecular data and reconstruction of morphological character evolution in Asian Impatiens section Semeiocardium (Balsaminaceae). Systematic Botany 40(4): 1063-1074. https://doi.org/10.1600/036364415X690102

Ruchisansakun S, Tangtorwongsakul P, Cozien R, Smets E, Van Der Niet T (2016) Floral specialization for different pollinators and divergent use of the same pollinator among cooccurring Impatiens species (Balsaminaceae) from Southeast Asia. Botanical Journal of the Linnean Society 181(4): 651-666. https://doi.org/10.1111/boj.12427

Ruchisansakun S, Suksathsan P, Van der Niet T (2017) Impatiens tanintharyiensis (Balsaminaceae), a new species from southern Myanmar. Phytotaxa 296(2): 171-179. https://doi. org/10.11646/phytotaxa.296.2.6

Ruchisansakun S, Suksathan P, van der Niet T, Smets EF, Saw-Lwin, Janssens SB (2018) Balsaminaceae of Myanmar. Blumea 63: 199-267. https://doi.org/10.3767/blumea.2018.63.03.01

Shimizu T (1970) Contributions to the Flora of Southeast Asia II. Impatiens of Thailand and Malaya. South Asian Studies 8: 187-217.

Shimizu T (1977) Some additional note on Impatiens (Balsaminaceae) of Thailand. Acta Phytotaxonomica et Geobotanica 23: 31-34.

Shimizu T (1991) New species of the Thai Impatiens (1). Shokubutsu Kenkyu Zasshi 66: 166-171.

Shimizu T (2000) New species of Thai Impatiens (Balsaminaceae) 2. Bulletin of the National Science Museum, Series B (Botany) 26: 35-42.

Shimizu T, Suksathan P (2004) Three new species of the Impatiens (Balsaminaceae), part 3. Bulletin of the National Science Museum, Series B (Botany) 30: 165-171.

Souvannakhoummane K, Suksathan P (2015) Two new species of Impatiens (Balsaminaceae) from north of Lao PDR. Taiwania 60(4): 175-180. https://doi.org/10.6165/ tai.2015.60.175

Suksathan P, Triboun P (2009) Ten new species of Impatiens (Balsaminaceae) from Thailand. Gardens' Bulletin (Singapore) 61: 159-184.

Wight R, Arnott W (1834) Prodromus Florae Peninsulae Indiae Orientalis 1. Parbury, Allen \& Co, London, 480 pp. http://dx.doi.org/10.5962/bhl.title.252

Yu SX, Janssens SB, Zhu XY, Lidén M, Gao TG, Wang W (2015) Phylogeny of Impatiens (Balsaminaceae): Integrating molecular and morphological evidence into a new classification. Cladistics 32: 1-19. https://doi.org/10.1111/cla.12119 